Nat. Hazards Earth Syst. Sci. Discuss., https://doi.org/10.5194/nhess-2017-382

Manuscript under review for journal Nat. Hazards Earth Syst. Sci.

Discussion started: 11 January 2018

(c) Author(s) 2018. CC BY 4.0 License.

\title{
3-Dimensional modeling of 2014-Malin Landslide, Maharashtra using satellite-derived data: A quantitative approach to numerical simulation technique
}

\author{
Shovan Lal Chattoraj ${ }^{1}$, Prashant K. Champati ray ${ }^{1}$, Sudhakar Pardeshi ${ }^{2}$, Vikram Gupta ${ }^{3}$, Yateesh \\ Ketholia $^{1}$ \\ Affiliation: ${ }^{1}$ Indian Institute of Remote Sensing, 4-Kalidas Road, Dehradun-248001 \\ ${ }^{2}$ Univeristy of Pune, Ganeshkhind, Pune, Maharashtra-411007 \\ ${ }^{3}$ Wadia Institute of Himalayan Geology, 33, GMS Road. Dehradun-248001

\section{Corresponding Author:} \\ Shovan Lal Chattoraj \\ Email: shovan.iitb@gmail.com \\ Phone: 0135-2524157
}

\section{Abstract:}

Debris flows, a type of landslides, are not nowadays limited only to the periodic devastation of the geologically fragile Himalaya but also ubiquitous in weathered Deccan Volcanic Province of the cratonic south Indian peninsula. Comprehensive assessment of landslide hazard, pertinently, requires process-based modeling using simulation methods. Development of precipitation triggered debris flow simulation models of real events are still at a young stage in India, albeit, especially in tectonically less disturbed regions. A highly objective simulation technique has therefore been envisaged herein to model the debris flow run-out happened in Malin. This takes cues from a highresolution DEM and other ancillary ground data including geotechnical and frictional parameters. The algorithm is based on Voellmy frictional (dry and turbulent frictional coefficients, $\mu$ and $\xi$ respectively) parameters of debris flow with pre-defined release area identified on high-resolution satellite images like LISS-IV and Cartosat-1. The model provides critical quantitative information on flow 1) Velocity, 2) Height, 3) Momentum, and 4) Pressure along the entrainment path. The simulated velocity of about $16 \mathrm{~m} / \mathrm{s}$ at mid-way the slide plummeted to $6.2 \mathrm{~m} / \mathrm{s}$ at the base with intermittently increased and decreased values. The simulated maximum height was $3.9 \mathrm{~m}$ which gradually declined to $1.5 \mathrm{~m}$ near the bottom. The results can be beneficial in engineering intervention like the construction of check dams to digest the initial thrust of the flow and other remedial measures designed for vulnerable slope protection.

Key Words: landslide, debris flow, Malin, simulation, satellite image. 
Nat. Hazards Earth Syst. Sci. Discuss., https://doi.org/10.5194/nhess-2017-382

Manuscript under review for journal Nat. Hazards Earth Syst. Sci.

Discussion started: 11 January 2018

(c) Author(s) 2018. CC BY 4.0 License.

\section{Introduction:}

Mass wasting - a general term for all kind of movements, has become a treacherous issue in the Himalaya. Quite frequently, especially during rainy season, landslides are witnessed in Lesser and Central Himalaya causing severe loss to man and property. Moreover, these landslides may lead to some critical problems such as blockade of rivers, which may incite secondary catastrophic disaster such as floods, as was the case in 2013-Kedarnath Tragedy in the Uttarakhand Himalaya. Off late, Sahyadri hills in the Western Ghats have witnessed many landslides, particularly during the rainy season, causing severe loss to humankind and property (Gujarathi and Mane, 2015).

Considering the graveness of the issue, many researchers and experts have analyzed landslides from all perspectives, i.e., to model, predict or to design preventive measures. Subsequently, the number of well-tested and documented empirical methods have been evolved to determine dynamic and kinematic parameters of the flow. However, some numerical simulation techniques are more preferred to predict flow paths and characterize the entrainment process (Tsai et al. 2011; Quan Luna et al. 2011, Evans et al. 2011). The underlying principle of such events can be applied to a variety of processes including snow avalanche. Debris flows, landslides, mudflows and even rock falls and has therefore found to be significant in disaster management. Although well tested empirical methods adopted by Heim 1932, Scheidegger 1973, Corominas, 1996, Nicolettiand Sorriso-Valvo, 1991, Li, 1983, Hungr, 1995 are available to determine dynamic characteristics of a flow, numerical simulation techniques, such as Hungr, 2006, Iverson, 1997, Savage and Hutter, 1989, Chen and Lee ,2000, Iverson and Delinger, 2001, McDougall and Hungr, 2004, Sousa and Voight, 1991, Hungr, 1995 (DAN), Volellmy, 1955, Hungr and Evans,(DAN 3D ), 1996, 2004, Hungr and McDougall,2009 are now being widely applied to predict flow paths and characterize the entrainment process.

Pertinently, as for the Indian subcontinent, the Himalayan region has experienced many devastating landslides in the past. Most of the landslides in the Himalayan region have a major debris flow component that travels some distance causing enormous damage enroute (Chattoraj, 2016, Chattoraj and Champati ray 2015; Champati and Chattoraj, 2014). On the contrary, debris flows are less abundant in Western Ghats. However, most of the works mentioned above, reports either the geoengineering aspects of landslides or hazard/ susceptibility mapping leading to damage assessment. Comprehensive assessment of landslide hazard which requires process based modeling using numerical simulation methods is still lacking or at nascent stage in Indian subcontinent as a whole. 
Nat. Hazards Earth Syst. Sci. Discuss., https://doi.org/10.5194/nhess-2017-382

Manuscript under review for journal Nat. Hazards Earth Syst. Sci.

Discussion started: 11 January 2018

(c) Author(s) 2018. CC BY 4.0 License.

Precipitation triggered debris flow models have, albeit, been attempted in similar tectonically disturbed regions of the world and holds tremendous opportunity in implementation of a successful strategy for landslide hazard mitigation (Brand 1995, Champati ray et al. 2013, Deganutti et al. 2000; Hungr et al. 1987; Scott 2000). The present study aims to fill this knowledge gap by focusing on numerical analysis of major landslides/debris flow movements and simulate landslides that occurred in the Western Ghats. This study leads to derivation of the important physical flow parameters taking cues from Earth Observation techniques to understand the root cause of the devastation, which is essential for effective mitigation measures.

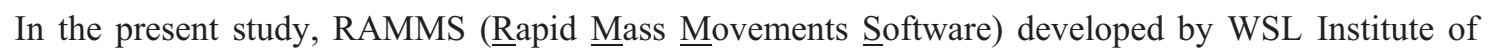
Snow and Avalanche, Switzerland has been used, which is a state-of-the-art numerical simulation model that predicts the motion of a naturally occurring mass from a head (release area) to base (deposition area) in three dimensions. The present study aims to address landslides/debris flow movement and simulate the landslide event that had occurred in the Malin area, the northern part of the Sahyadri hill, in the wee hours of $30^{\text {th }}$ July 2014 following torrential rainfall. It engulfed 40 houses and gobbled up 151 people as per. The event was classified as an unchannelized debris flow consisting mainly of semi-consolidated, basalt-derived, silt to coarse sand-sized, poorly sorted soil, highly saturated with water which was triggered by intense monsoonal precipitation on leeward side of a slope underlain by thick alternating basaltic layers of varied composition and physical characteristics (Champati ray and Pardeshi, 2014).

The outputs of such simulated flows are likely to provide the stake holders actual insight of the cause of these events and associated disasters. Extensive landslide mapping at large scales complimented by this kind of 3-dimensional modeling of landslides will provide adequate information to understand the event and plan for the mitigation measures in future (Champati ray et al. 2013; Herva'set et al. 2003).

\section{Study area and location}

Malin village is located at latitude $19^{\circ} 09^{\prime} 40.84$ ' $\mathrm{N}$ and longitude $73^{0} 41^{\prime} 18.41$ ' $\mathrm{E}$ from $775 \mathrm{~m}$ (avg.) above MSL (SOI Toposheet no. E43B/12) on a southeasterly facing slope of a small valley oriented along the NNE-SSW direction (Fig. 1). Downhill Malin village, a streamlet flows in SE direction which meets Bubranadi, a tributary of Ghod river, which in turn becomes contributory to Bhima 
Nat. Hazards Earth Syst. Sci. Discuss., https://doi.org/10.5194/nhess-2017-382

Manuscript under review for journal Nat. Hazards Earth Syst. Sci.

Discussion started: 11 January 2018

(c) Author(s) 2018. CC BY 4.0 License.

river. The Bhima river system forms part of the Upper Godavari basin. The Ghod river is dammed at Ambegaon forming the Dimbhe reservoir. This reservoir is fed by two significant inlets, the northern one of which flows close to Malin. Besides the main Dimbhe dam, there is a small dam at $9 \mathrm{~km}$ upstream on the Bubranadi. The upstream tail end limit of this reservoir water stops at about $1 \mathrm{~km}$ away from Malin village in the upstream direction.

\section{Regional Geology and Geomorphology:}

Geologically, the Malin and adjoining area are embedded/overlain by Deccan Volcanic Province (DVP) of peninsular India consisting of numerous horizontal to gently dipping/inclined lava flows. The flows are characteristically transacted by linear discontinuities like parallel joints and fractures which are revealed (or reflected) in the form of lineaments and drainage systems have developed (along these discontinuities). The major trend of the lineaments are observed to be NW-SE and NNE/NE - SSW/SE directions (Champati ray and Pardeshi, 2014; Ramaswami et al. 2015). GSI, 1995 has defined three types of lava flows viz.1) fine-grained aphyric pahoehoe flows (Karla Formation), 2) Aphyric to sparsely phyric flows and Megacryst flow(Indrayani Formation), 3) fine to medium grained aphyric flows (Upper Ratnagarh Formation). These formations, in total, accommodates 14 flows (Champati ray and Pardeshi, 2014).

In this area, the Sahyadri range is divided into two parts viz.1) high hills and adjoining plains located in the western part and 2) denudational hills and associated river valleys (Ghod and Bhima river)in the eastern part (Fig. 2). The study area falls in the second part. However, both the hill ranges show extensive plateau development owing to horizontal nature of lava flows. The small valley near Malin is located at an elevation of $680 \mathrm{~m}$, the village itself at $700-710 \mathrm{~m}$, followed by terrace at $750 \mathrm{~m}, 800$ and $840 \mathrm{~m}$ on Cartosat-1 stereo-pair derived DEM. On SRTM DEM, the valley is located at $750 \mathrm{~m}$, Malin village at $770 \mathrm{~m}$, the terrace at 827 and $940 \mathrm{~m}$. Overall the relief difference is around $160-180 \mathrm{~m}$ from the valley bottom to hilltop with an average slope of $11-13^{0}$, and on the steepest section, the slope is $21^{0}$.

\section{Methodology and input data}

Multi-temporal and multi-resolution Earth Observation satellite data products and derived information have been used to set parameters for flow modeling (table 1). Flow modeling has been developed and validated against the actual events of 2014 by ground checking. 
Nat. Hazards Earth Syst. Sci. Discuss., https://doi.org/10.5194/nhess-2017-382

Manuscript under review for journal Nat. Hazards Earth Syst. Sci.

Discussion started: 11 January 2018

(c) Author(s) 2018. CC BY 4.0 License.

\subsection{Satellite Data used:}

Indian Remote Sensing Satellite data products such as LISS-IV (Resourcesat 2) data sets acquired on $8^{\text {th }}$ January, and Cartosat-1 data acquired on $3^{\text {rd }}$ March 2011 were analyzed mainly for pre-event analysis (Table 1). Post-event changes were compared using LISS-IV ( $1^{\text {st }}$ Feb 2015) and Cartisat-1 (6 ${ }^{\text {th }}$ April 2015). DEM (Res. 10m) was generated using pre-event Cartsat-1 stereo-pair in LPS module of Erdas Imagine software (v. 2014). Ancillary Earth observation data like SPOT images of Google Earth and terrain information derived from SRTM DEM Version 4 were also referred as detailed in table1.

\subsection{Debris flow run-out modeling}

The essential dataset required for the physically based model are topographic data (digital elevation model), release area and release mass as well as information on friction for dry and liquid phases and geo-engineering parameters like an internal shear angle and density. Topographical data sets in the form of high-resolution digital elevation model (DEM) and the location of release area are the two most important parameters for flow modeling. DEM in the form of the ESRI ASCII Grid and ASCII $\mathrm{X}, \mathrm{Y}, \mathrm{Z}$ format is required for implementation.

Debris flow modeling for unchannelized flows (as observed in the present case) requires a known release area with a given initial height for block release (Rickenmann D 1999, Rickenmann, 2005; Rickenmann et al. 2006). Therefore, the release areas for debris flows have been identified using high-resolution satellite images (Cartosat-1 and LISS-IV) and derived DEM. The initiation zone in the study area is steeper with slope angle ranging between $30-70^{\circ}$ with height varying from $925 \mathrm{~m}$ to $765 \mathrm{~m}$. The depth of the initiation zone (depletion zone) varies from $1 \mathrm{~m}$ to $1.2 \mathrm{~m}$ (Fig. 3,4). The field observations revealed that the modeled landslide was initiated with weathered basalt derivatives/ debris and when it hit Malin village width of the slide was maximum $(\sim 150 \mathrm{~m})$.

\subsection{Frictional parameters}

The RAMMS numerical simulation model is based on rheological characters of the slope derived from shear strength parameters of the slope. This model divides the frictional resistance into two parts: a dry-Coulomb type friction (coefficient, $\mu$ ) and a velocity-squared drag or viscous-turbulent friction (coefficient, $\xi$ ). The frictional resistance $\mathrm{S}(\mathrm{Pa})$ is then defined as:

$\mathrm{S}=\mu \rho \mathrm{Hg} \cos (\varphi)+\left(\rho g \mathrm{U}^{2}\right) / \xi$ 
Nat. Hazards Earth Syst. Sci. Discuss., https://doi.org/10.5194/nhess-2017-382

Manuscript under review for journal Nat. Hazards Earth Syst. Sci.

Discussion started: 11 January 2018

(c) Author(s) 2018. CC BY 4.0 License.

Where $\rho$ is the density, $g$ the gravitational acceleration, $\varphi$ the slope angle, $H$ the flow height and $U$ the flow velocity (Salm et al. 1990). The two major frictional input parameters are $\mu$ and $\xi$. However, it is known from a law of friction that $\mu=\tan \varphi$, where $\varphi$ is an angle of internal resistance that can be determined in the laboratory. In the present case, direct shear test instrument was used to determine c (cohesion) and angle of internal friction from soil samples collected from the study area.

The main difficulty in case of debris flow simulation is the much larger variety of debris flow materials, which influence the choice of the friction parameters. RAMMS Debris Flow uses a singlephase model, and it cannot distinguish between fluid and solid phases, and the entire mass is modeled as a bulk flow. Therefore, the friction parameters should be varied to match the observed flow paths in case of known debris flow events. It is quite possible that different events in the same torrent may show differences in composition. This fact makes the calibration of the friction parameters much more difficult. Therefore, numbers of simulations with different values for dry and viscous turbulent frictional coefficients were carried so that there is a close match between the modeled flow run out and actual field/ satellite photograph observations. The results were validated with field data, and the best-fitted simulation outputs were adopted for final analysis (Sosio et al. 2008).

Thus, some simulations were considered using various possible ranges of friction parameters. To find the optimal friction values, a range of values were used. The range of dry friction ranges from 0.05 to 0.5 and for viscous turbulent flow is $100-800 \mathrm{~m} / \mathrm{s}^{2}$ (Sosio et al. 2008). Meanwhile other input parameters viz. density of materials, release height, earth pressure coefficient (lambda) and the percent of momentum were kept constant. Afterward, validation of simulation outputs was done comparing the total length of run-out distance, and the aerial extent of run out vis-a-vis the actual flow paths on the ground.

When the simulated flow spatially matched approximately 97\% (pixel-wise) with real event, model parameters were frozen at $\mu(\mathrm{Mu})=0.49, \zeta(\mathrm{Xi})=460 \mathrm{~m} / \mathrm{s}^{2}$ and cohesion (c) value of $100 \mathrm{kPa}$. For dry friction value, it was observed from that an increase in the friction coefficient $\mu(\mathrm{Mu})$ causes a decrease in the run-out distance due to increase in the basal friction of the flow. On the other hand, the value of $\zeta(\mathrm{Xi})$ changes did not affect the run-out distance significantly. However, in general case, an increase in $\zeta(\mathrm{Xi})$ value increases the run-out distance and results in a relatively smoother flow.

Amongst RAMMS model outputs, momentum is not absolute as it simply considers momentum as a product of flow height and velocity. Thus the unit is $\mathrm{m}^{2} / \mathrm{s}$. To get real momentum in $(\mathrm{kg} * \mathrm{~m} / \mathrm{s})$, this 
Nat. Hazards Earth Syst. Sci. Discuss., https://doi.org/10.5194/nhess-2017-382

Manuscript under review for journal Nat. Hazards Earth Syst. Sci.

Discussion started: 11 January 2018

(c) Author(s) 2018. CC BY 4.0 License.

value is multiplied by the density of debris and area under consideration. Additionally, this numeral simulation model does not include 1) en-route erosion and 2) side channel contribution to the main flowing mass along run out. In most of the cases, variation in output geophysical parameters is reported due to above reason. Therefore, maximum valuation of parameters has been provided with error values. The outputs bound within error limits ensure that run out is restricted to the real debris flow channel as verified in the field and/or satellite image.

\section{Instrumental validation of Shear strength parameters}

RAMMS numerical simulation derived models require cohesion (c) and the frictional coefficient for dry and liquid phases ( $\mu$ and $\xi$ respectively) for soil/ debris as inputs. Cohesion is independent of stress systems and is dependent more on geochemical properties of the material. Frictional coefficient (static) for dry debris phase $(\mu)$ is related to the topographic slope by the rule of friction: $\tan \varphi=\mu$ (considering the angle of sliding equal to the angle of repose). Thus, theoretically, the instrument derived and modeled inputs of shear strength parameters of a successful simulation should match, if assumptions are within the error range. Direct shear instrument was utilized to measure cohesion (c) and angle of internal resistance $(\varphi)$ assuming prevailing maximum in-situ saturation level. The outputs of the direct shear instrument were plotted in the bivariate plot using Mohr-Coulomb equation, i.e., $\tau=\sigma \tan \varphi+\mathrm{c}$ which is a straight line equation between normal and shear stress plot. As each model is frozen once it approximates the real debris flow and its $\mu$ and $\varphi$ are cross-checked with the instrumentally derived $\mathrm{c}$ and $\varphi$ values from the soil sample. It is to be noted that when shear strength model inputs in RAMMS model and instrument derived outputs are comparable, then it is considered that simulation model validates well with the real world situation.

The representative samples collected from the base of the flows were analyzed in electronic direct shear testing equipment (Model No. AIM $104(2 \mathrm{kN})$, Make Aimil Ltd, New Delhi) at Indian Institute of Remote Sensing, Dehradun at different saturation levels. Samples were tested at 0.25, 0.50 and 1 $\mathrm{kgf} / \mathrm{cm}^{2}$ normal load and consequent shear strength parameters at failure was calculated. The input dry coefficient of friction fed in the model was thus was further crosschecked instrumentally. The Mohr-Coulomb equation revealed that the cohesion (c) and angle of internal shear resistance $(\varphi)$ of semi-consolidated debris which is $98-116 \mathrm{KPa}$ and $25-32^{\circ}$ (i.e. $\mu=0.4$ to 0.6 ) respectively which are at par with modeled inputs. 
Nat. Hazards Earth Syst. Sci. Discuss., https://doi.org/10.5194/nhess-2017-382

Manuscript under review for journal Nat. Hazards Earth Syst. Sci.

Discussion started: 11 January 2018

(c) Author(s) 2018. CC BY 4.0 License.

\section{Results and Discussion:}

The debris flow reached the maximum height of approximately $3.9 \mathrm{~m}$ near the release area (Fig. 5). It consistently decreased to 1 meter with slide's propagation. However, the height suddenly rose around the toe of the slide, probably to conserve momentum. The maximum velocity of about $16 \mathrm{~m} / \mathrm{s}$ was attained somewhere mid-way the slide. The velocity profile of the slide is zigzag with fluctuating velocities. The velocity near release area was $10 \mathrm{~m} / \mathrm{s}$, which intermittently increased and decreased during the entire sliding event. The velocity at toe modeled to be to be $5-6 \mathrm{~m} / \mathrm{s}$-sufficient enough to bury a village! The sliding mass had maximum momentum in the lower half of the profile probably due to the attainment of maximum velocity mid-way. The value of momentum near the release area was around $8-9 \mathrm{~m}^{2} / \mathrm{s}$, which then decreased and again increased to a maximum of $26 \mathrm{~m}^{2} / \mathrm{s}$ and then gradually dwindled down to rest(Fig. 5).The pressure more or less followed the footprint of velocity with fluctuating values throughout the landslide event. Henceforth, the maximum value of $440 \mathrm{KPa}$ was reached somewhere near the middle(Fig. 5).

This work enhanced the understanding of numerical models by studying their resemblance with real landslide/debris flow that contributed to the unprecedented disaster in Malin. The vital output parameters viz. velocity, height, momentum, and pressure can be used to provide insight of the event and extent of runout zone of future potential flows which also helps in the understanding of slope stability. Thus, this work bespeaks that numerical simulation modeling is capable of emulating natural events and outputs can be used for mitigation measures. The results can be very useful in engineering intervention like a construction of check dams to digest the initial thrust of the flow and other remedial measures designed for vulnerable slope protection. Integrated with extensive landslide mapping, 3-dimensional modeling of landslides will complimentarily provide the stakeholders actual insight of the cause of this type of event vis-à-vis its effective corrective measure. The model has not only produced reliable simulation results but also established the efficacy and versatility in application of models in a wide range of mass wasting events about different causative factors.

\section{Conclusion:}

Three-dimensional modeling of natural debris flow events by the satellite image-based analysis provided two most important results. First of all, the study provided a successful simulation of selected debris flow events and generated output parameters such as velocity, height, pressure, and 
momentum taking inputs from remotely sensed and ancillary earth observation data products. Secondly, it provided critical insight into the events and their consequences. Based on the study, it is concluded that the modeled flows have provided debris with sufficient height, velocity, and momentum that devastated the whole area. The maximum height of the debris has been revealed to approximately $4 \mathrm{~m}$ which along entrainment path got attenuated by mainly by the change in slope. However, to be on the safer side, it can be concluded that any check dam to arrest the flow and digest initial thrust of the debris impact should be more than this height for this particular debris flow. This study shows that rough estimation of heights of check dams for similarly vulnerable slopes can be done by the development of such models in a simple but fast methodology. Spatial variation of velocity and momentum of such flows can provide vital inputs to develop the design and extent of remedial measures.

For further refinement of modeled outputs, influences of side-wise mass contribution, en-route erosion, an influence of rheology and pore-pressure, relationship between discontinuity vis-à-vis topography should be considered. The actual outputs can still be on the higher side as the model does not include side-channel contribution and en-route erosion. Moreover, simulation output is required to be verified with the previously modeled event as a part of validation strategy. In this context, the input parameters are important because these parameters would affect the simulation results. Rather validation was carried out on collected field data in terms of their shear strength parameters and flow characteristics. In this regard to get real field data, it is always recommended to collect such data at the earliest after an event.

\section{Acknowledgement:}

Contributions of students and JRFs like Shobhana, Sweta and Gopal in different phases have helped immensely to shape the paper. Organizational support and overall guidance provided by Dr. A. Senthil Kumar, Director, IIRS and Dr. SPS Kushwaha, Ex-Dean (Academics) are also duly acknowledged. Helps received from former Director of IIRS is placed on record. SLC and PKC is thankful to Indian Space Research Organization, Department of Space, Government of India for the financial support provided in TDP project. 
Nat. Hazards Earth Syst. Sci. Discuss., https://doi.org/10.5194/nhess-2017-382

Manuscript under review for journal Nat. Hazards Earth Syst. Sci.

Discussion started: 11 January 2018

(c) Author(s) 2018. CC BY 4.0 License.

\section{References:}

Brand E.W., 1995. Slope instability in tropical areas: in Bell (ed.), Proceedings of the Sixth International Symposium on Landslides, 10-14 February 1992, Christchurch, New Zealand, A.A. Balkema, Rotterdam 3: 2031-2051.

Champati ray PK, Chattoraj SL., 2014. Sunkoshi landslide in Nepal and its possible impact in India: a remote sensing based appraisal. International Archive of ISPRS, Commission VIII (WG VIII/1), pp $1345-1351$

Chattoraj SL and Champati ray PK (2015) Simulation and modelling of debris flows using satellite derived data: A case study from Kedarnath area. International Journal of Geomatics and Geosciences 6(2):1498-1511

Chattoraj, SL (2016). Debris Flow Modelling and Risk Assessment of Selected Landslides from Uttarakhand- Case Studies using Earth Observation Data, In: Santra, A. and Mitra, S., (Eds.), Remote Sensing Techniques and GIS Applications in Earth and Environmental Studies. IGI Global Publication, Hershey, Pennsylvania, pp. 111-121. ISBN: 978-1-5225-1814-3.

Champati ray, P.K. and Pardeshi, S. 2014.Preliminary analysis of Malin landslide, Maharashtra using satellite data.Indian Landslides, Vol. 7 (1 \& 2), 1-8.

Champati ray PK, Chattoraj SL, Chand DS, Kannaujiya S (2013) Aftermath of Uttarakhand disaster 2013: an appraisal on risk assessment and remedial measures for Yamunotri shrine using satellite image interpretation. Indian Landslides, 6 (2):61-70

Chen H. and Lee C.F.,2000.Numerical simulation of debris flows. Canadian Geotechnical Journal, 37: $146-160$.

Corominas, J., 1996. The angle of reach as a mobility index for small and large landslides. Canadian Geotechnical Journal 33: 260-271.

Deganutti AM, Marchi L, Arattano M (2000) Rainfall and debris-flow occurrence in the Moscardo basin (Italian Alps): in Wieczorek, G.F., and Naeser, N.D., eds., Debris-Flow Hazards Mitigation: Mechanics, Prediction, and Assessment: Proceedings of the Second International Conference, Taipei, Taiwan, August 16-18, 2000, A.A. Balkema, Rotterdam, pp. 67-72.

Ering, P. and SivakumarBabu, G.L., 2016. Probabilistic back analysis of rainfall induced landslide-A case study of Malin landslide, India. Engineering Geology, 208: 154-164.

Evans, S.G., Hermanns, R.L., Strom, A., Scarascia-Mugnozza, G. (Eds.) 2011.Natural and Artificial Rockslide Dams.Springer-Verlag, Berlin, Heidelberg, pp. 463-477. ISSN: 0930-0317 
Nat. Hazards Earth Syst. Sci. Discuss., https://doi.org/10.5194/nhess-2017-382

Manuscript under review for journal Nat. Hazards Earth Syst. Sci.

Discussion started: 11 January 2018

(c) Author(s) 2018. CC BY 4.0 License.

Gujarathi, P and Mane, S. J. 2015.Landslides Zones of Nearby Areas of Malin Village,Pune District, Maharashtra Using GIS Techniques. International Journal of Science and Research, Vol. 4(7), 443448.

Heim, A., 1932, Bergsturz und Menschenleben, Fretz und Wasmuth, Zurich, 218 pp.

Hungr O., 1981.Dynamics of rock avalanches and other types of slope movements.Ph.D. thesis, University of Alberta, Edmonton, p. 500.

Hungr, Oldrich, Morgan, GC, VanDine, DF, Lister DR (1987) Debris flow defenses in British Columbia, in Costa, J.E., and Wieczorek, G.F., eds., Debris flows/avalanches: Process, recognition and mitigation, Geological Society of America. Reviews in Engineering Geology 7:201-222.

Herva'set J, Barredo J.I., Rosin P.L., Pasuto A., Mantovani F., Silvano S., 2003. Monitoring landslides from optical remotely sensed imagery: the case history of Tessina landslide, Italy. Geomorphology 54:63-75

Hungr, O., 1995. A model for runout analysis of rapid flow slides, debris flows, and avalanches, Canadian Geotechnical Journal, 32, 610-623.

Hungr O., 2006. Rock avalanche occurrence, process and modelling. In Evans S.G. et al. (eds) Landslides from Massive Rock Slope Failure. NATO Advanced Workshop, Celano, Italy. NATO Science Series, Springer.

Hungr O. and Evans S.G. 1996.Rock avalanche runout prediction using a dynamic model. Proceedings 7th International Symposium on Landslides, Trondheim, Norway, 1: 233-238.

Hungr O. and Evans S.G., 2004. Entrainment of debris in rock avalanches; an analysis of a long runout mechanism. Bulletin, Geological Society of America, no. 9/10, 116:1240-1252.

Hungr, O. and McDougall, S. 2009. Two numerical models for landslide dynamic analysis. Computers \& Geosciences 35(5):978-992.

Iverson, R.M. 1997. The physics of debris flows. Reviews of Geophysics, 35: 245-296.

Iverson R.M. andDenlinger R.P., 2001.Flow of variably fluidized granular masses across threedimensional terrain. 1. Coulomb mixture theory, Journal ofGeophysical Research, 106: 537-552.

Li, T., 1983, A mathematical model for predicting the extent of a major rockfall, Zeitschrift fur Geomorphologie, 27 (4): 473-482.

McDougall, S. and Hungr, O., 2004.A model for the analysis of rapid landslide motion across threedimensional terrain, Can. Geotech. J., 41, 1084-1097. 
Nat. Hazards Earth Syst. Sci. Discuss., https://doi.org/10.5194/nhess-2017-382

Manuscript under review for journal Nat. Hazards Earth Syst. Sci.

Discussion started: 11 January 2018

(c) Author(s) 2018. CC BY 4.0 License.

Nicoletti P.G, Sorriso-Valvo M., 1991. Geomorphic controls of the shape and mobility of rock avalanches. Bulletin of the Geological Society of America 103 (10):1365-1373. Quan Luna B., Blahut, J, van Westen, C.J., Sterlacchini, S., van Asch T.W.J. and Akbas, S.O. 2011. The application of numerical debris flow modelling for the generation of physical vulnerability curves. Natural Hazards and Earth System Sciences 11: 2047-2060.

Ramasamy, S.M., Muthukumar, M. and Subagunasekar, M., 2015.Malin-Maharashtra landslides: a disaster triggered by tectonics and anthropogenic phenomenon, Current Science, 108 (8): 1428-30. Rickenmann D (1999). Emperical relationships for debris flows. Natural Hazards 19: 47-77.

Rickenmann, D. 2005. Runout prediction methods. In: M. Jakob\& O. Hungr (eds.), Debris-flow Hazard and Relation Phenomena, Chichester, Springer: 305-324.

Rickenmann, D., Laiglec, D, Mc. Ardell, B.W., Huebl, J. 2006. Comparison of 2d debris-flow simulation models with field events. Computers \& Geosciences 10: 241-264.

Salm, B., Burkhard, A., Gubler, H.U. 1990. Berechnung von Fliesslawinen: EineAnleitungfuerPraktiker; mitBeispielen. Mitteilungen des EidgenoessischenInstitutsfuerSchneeund Lawinenforschung 47: 1-37.

Savage S.B. and Hutter, K.,1989.The motion of a finite mass of granular material down a rough incline. Journal of Fluid Mechanics, 199: 177-215.

Scheidegger, A. E., 1973. On the prediction of the reach and velocity of catastrophic landslides, Rock Mechanics, 5: 231-236.

Scott K.M., 2000. Precipitation-triggered debris-flow at Casita Volcano, Nicaragua: Implications for mitigation strategies in volcanic and tectonically active steeplands. Paper published in Proceedings of the Second International Conference on Debris-Flow Hazards Mitigation: Mechanics, Prediction, and Assessment, Taipei, Taiwan, August 16-18, Rótterdam, pp 3-13

Singh, TN., Singh, R., Singh, B., Sharma, L.K., Singh, R., Ansari, M.K. 2016.Investigations and stability analyses of Malin village landslide of Pune district, Maharashtra, India. Natural Hazards, April 2016, Vol. 81, (3), 2019-2030.

Sosio, R., Crosta, G. B. and Hungr, O. 2008. Complete dynamic modeling calibration for the Thurwieser rock avalanche (Italian Central Alps). Engineering Geology 100: 11-26.

Sousa J. and Voight B. (1991) - Continuum simulation of flow failures.Geotechnique, 41: 515-538. 
Nat. Hazards Earth Syst. Sci. Discuss., https://doi.org/10.5194/nhess-2017-382

Manuscript under review for journal Nat. Hazards Earth Syst. Sci.

Discussion started: 11 January 2018

(c) Author(s) 2018. CC BY 4.0 License.

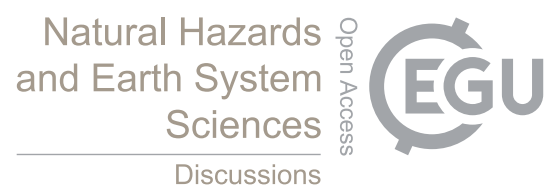

360 Tsai, M. P., Hsu, Y. C., Li, H. C., Shu, H. M. and Liu, K. F. 2011.Application of simulation 361 technique on debris flow hazard zone delineation: a case study in the Daniao tribe, Eastern Taiwan.

362 Natural Hazards and Earth System Sciences 11: 3053-3062.

363 Voellmy A (1955) Uber die Zerstorungskraft von Lawinen. SchweizBauzeitung 73:212-285.

364

365

366

367

368

369

370

371

372

373

374

375

376

377

378

379

Table Captions:

Table 1 Satellite data types and its sources

\section{Figure Captions:}

Figure. 1 Location map of the study area (Source: Astrium, May 3, 2016, (c) Google Earth). (Inset: study area shown in Indian map)

Figure. 2 Geomorphological map (1:50000) of a part of Pune District, Maharashtra (Source: Bhuvan, NRSC). Black and white line represent Pune district boundary and major road network respectively.

Figure 3.Filed photograph and satellite imagery. (a) Panoramic view of the Malin Landslide (Photograph taken on September, 2015). Field length of photograph $=250 \mathrm{~m}$; (b) SPOT Image, Apr, 03, 2015 (C) Google Earth); (c) Standard FCC of LISS IV, Jan 8, 2014 (RGB:321), Resourcest-2. Black circle highlights Malin village.

Figure 4. (a) Subset of DEM of Malin area showing source area (in violet) and area of influence (inside green boundary) of debris flow; (b) Elevation map Malin area

Figure. 5 Spatial variation of vital flow parameters of the debris flow model. (a) Momentum; (b) pressure; (c) velocity and (d) height. 
Nat. Hazards Earth Syst. Sci. Discuss., https://doi.org/10.5194/nhess-2017-382 Manuscript under review for journal Nat. Hazards Earth Syst. Sci.

Discussion started: 11 January 2018

(c) Author(s) 2018. CC BY 4.0 License.
Natural Hazards and Earth System Sciences

Discussions

\section{(c) (1)}

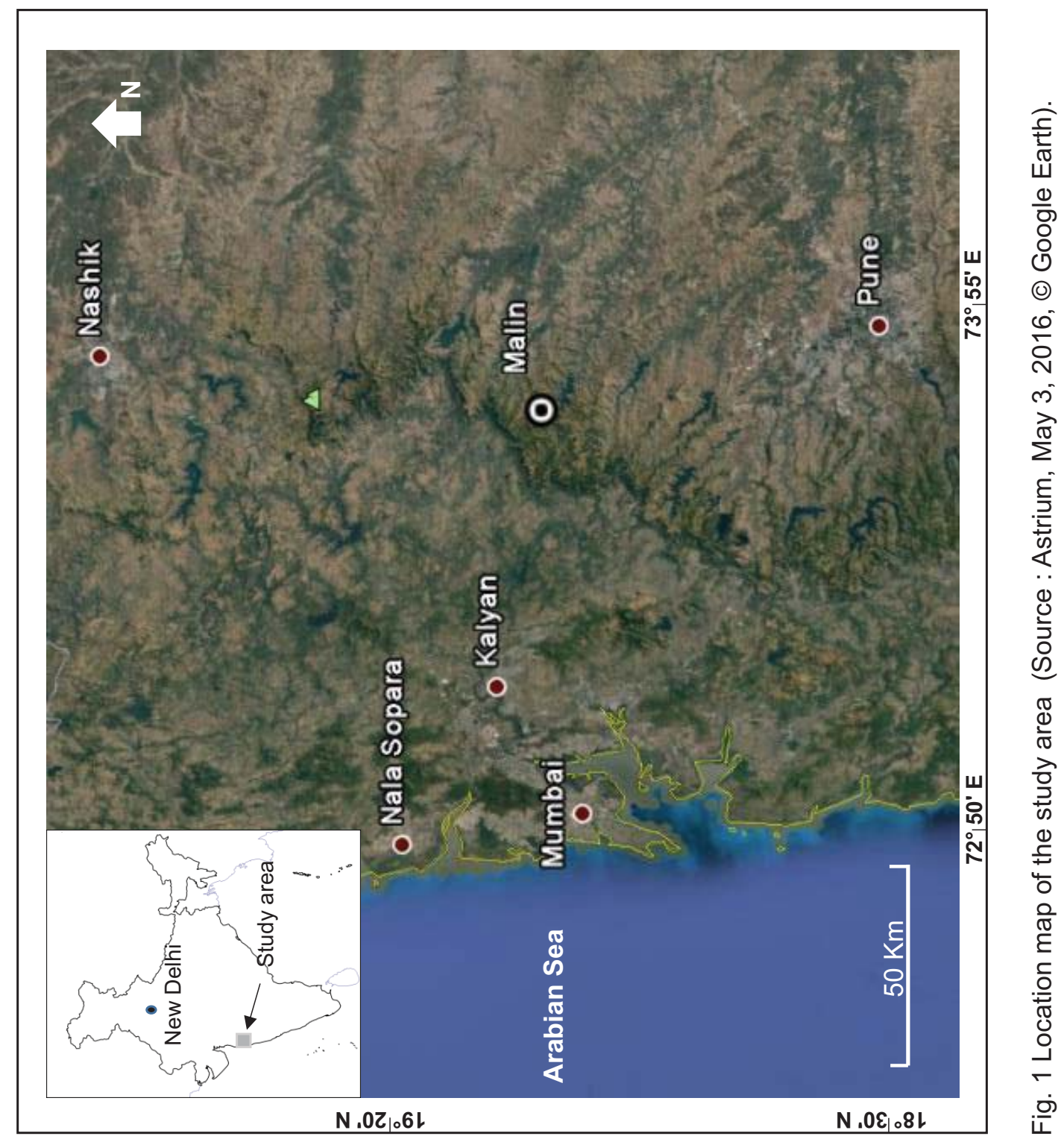


Nat. Hazards Earth Syst. Sci. Discuss., https://doi.org/10.5194/nhess-2017-382 Manuscript under review for journal Nat. Hazards Earth Syst. Sci.

Discussion started: 11 January 2018

(c) Author(s) 2018. CC BY 4.0 License.
Natural Hazards and Earth System

Sciences

Discussions

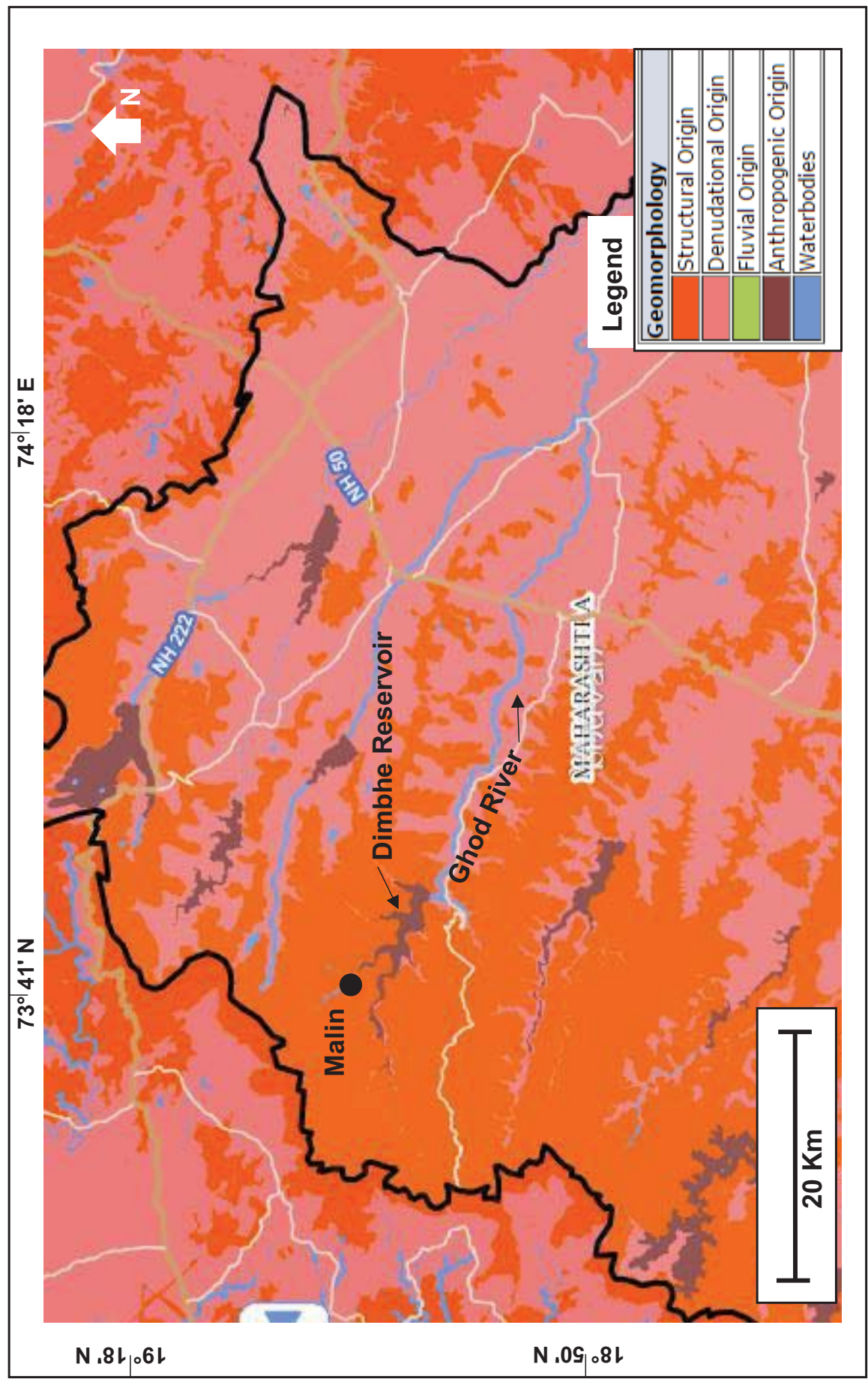

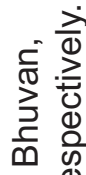

$\ddot{\theta}$

응 일

क्ष

준

क

들 음

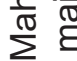

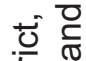

零?

元

()

ริำ

눙

는

2 잉

(ब)

प

응 뜸

8

華

$\doteq \frac{0}{0}$

은

$\stackrel{0}{\square}$

정

응

응 흥

흔

ह 음

ब $\bar{\square}$

ก

ํㅜㄴำ 
Nat. Hazards Earth Syst. Sci. Discuss., https://doi.org/10.5194/nhess-2017-382

Manuscript under review for journal Nat. Hazards Earth Syst. Sci.

Discussion started: 11 January 2018

(c) Author(s) 2018. CC BY 4.0 License.
Natural Hazards and Earth System Sciences

Discussions
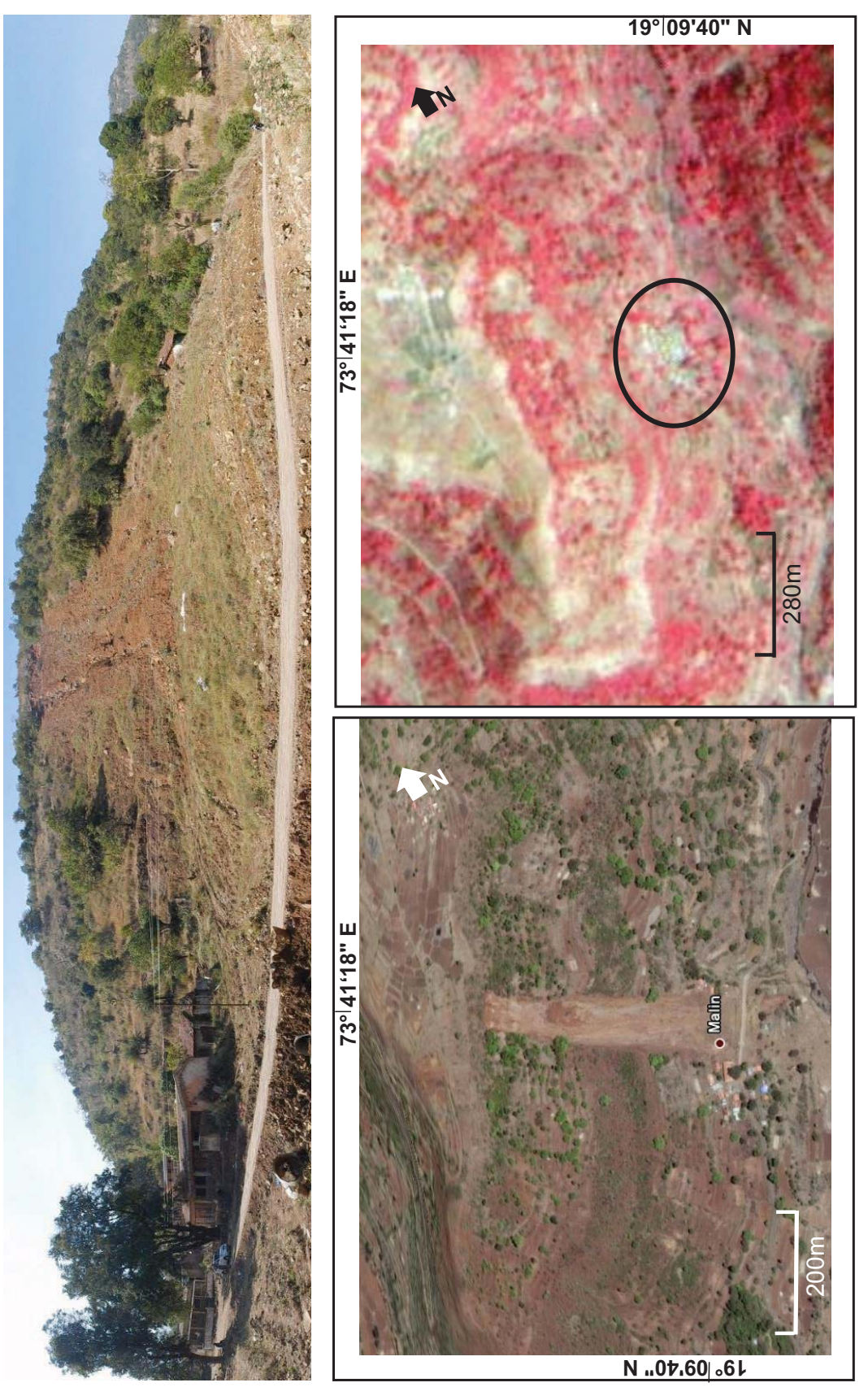

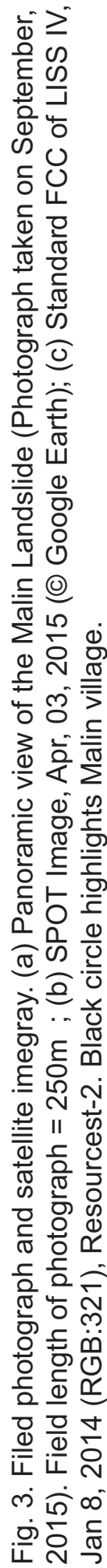


Nat. Hazards Earth Syst. Sci. Discuss., https://doi.org/10.5194/nhess-2017-382 Manuscript under review for journal Nat. Hazards Earth Syst. Sci.

Discussion started: 11 January 2018

(c) Author(s) 2018. CC BY 4.0 License.

\section{Natural Hazards and Earth System Sciences \\ Discussions}

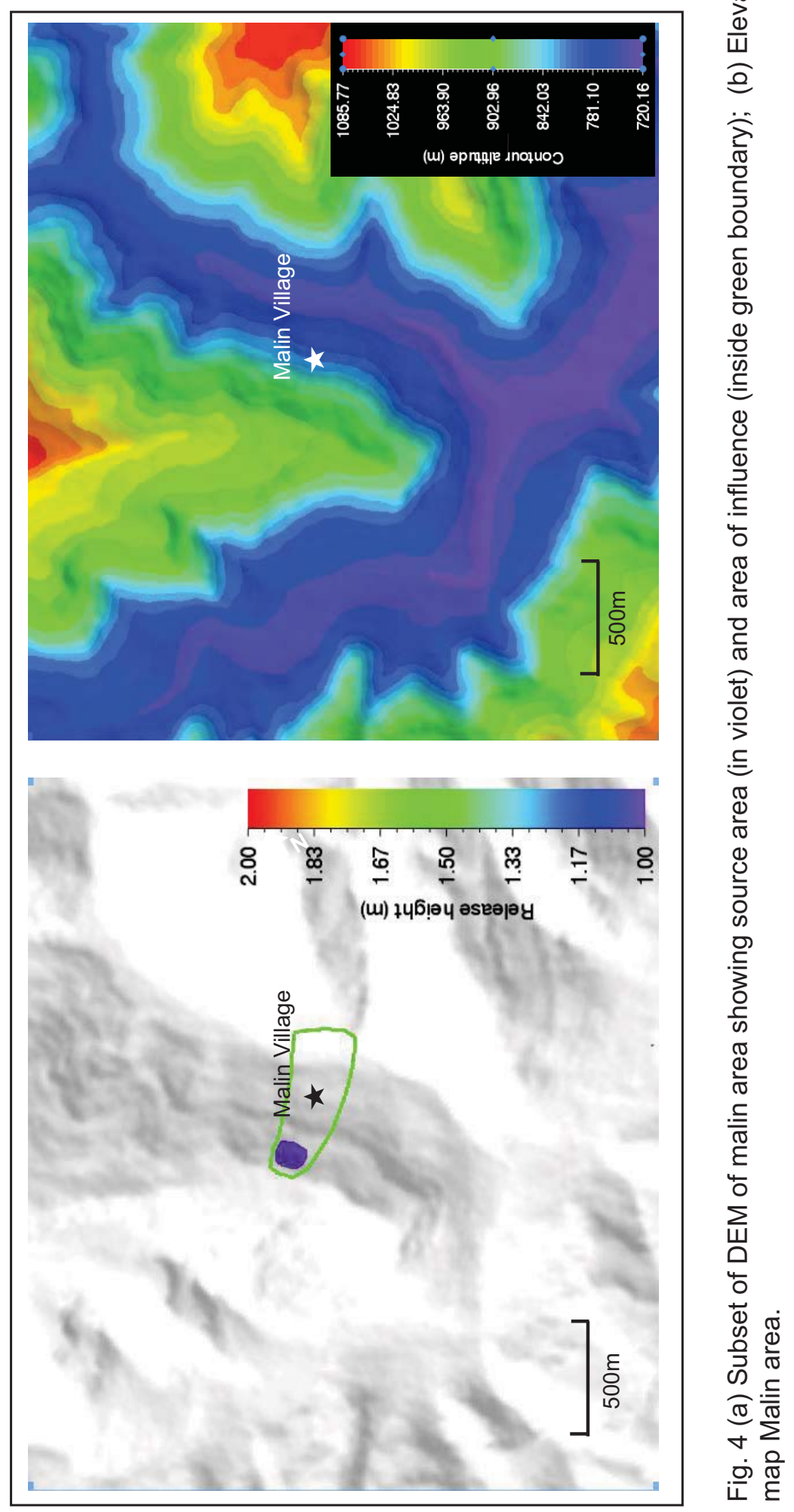


Nat. Hazards Earth Syst. Sci. Discuss., https://doi.org/10.5194/nhess-2017-382 Manuscript under review for journal Nat. Hazards Earth Syst. Sci.

Discussion started: 11 January 2018

(c) Author(s) 2018. CC BY 4.0 License.

\section{Natural Hazards and Earth System Sciences}

Discussions
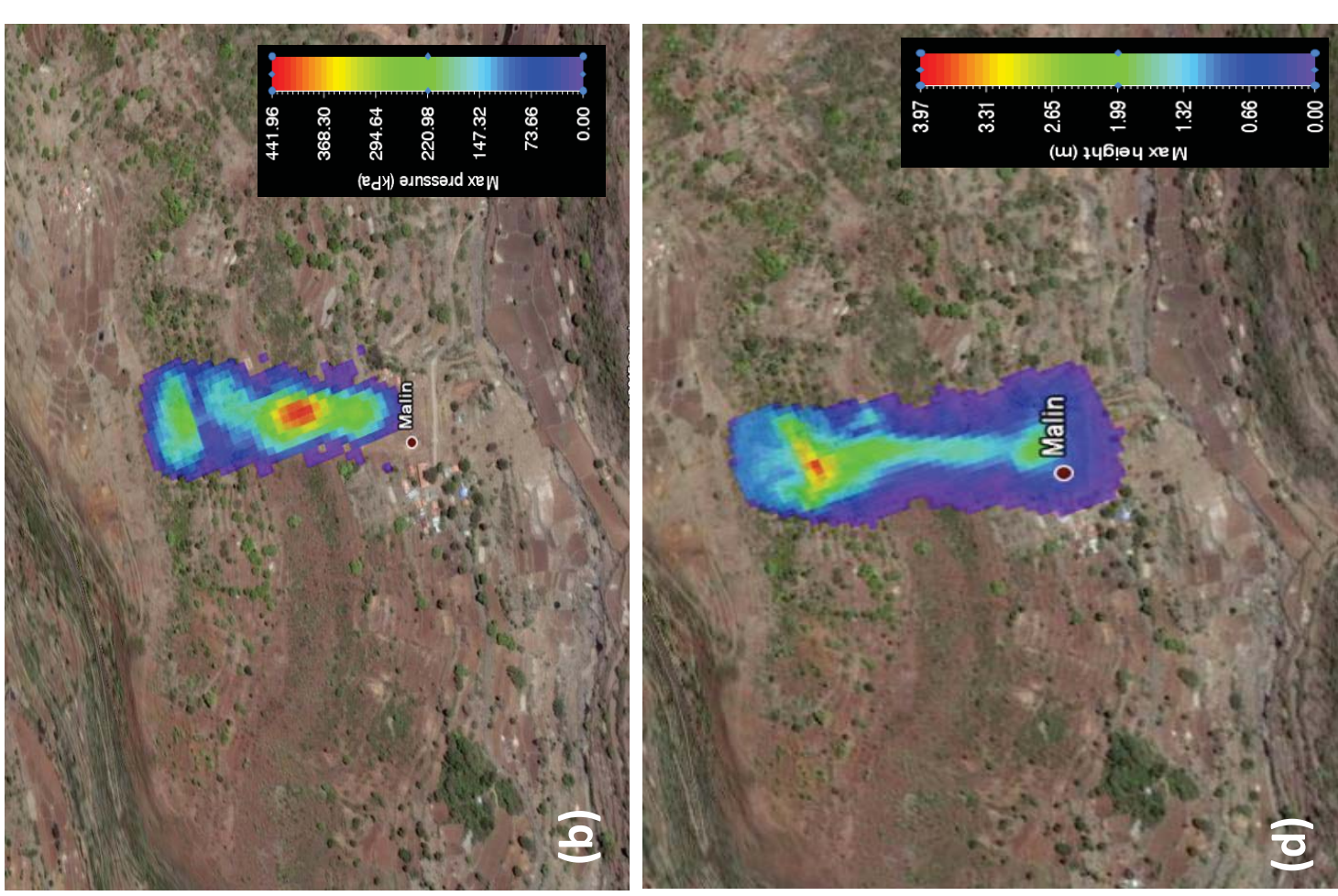

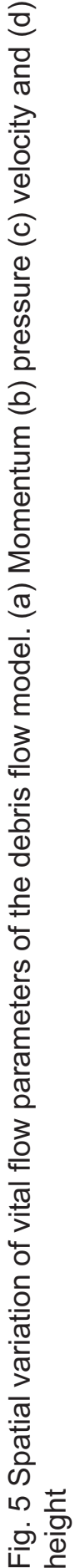
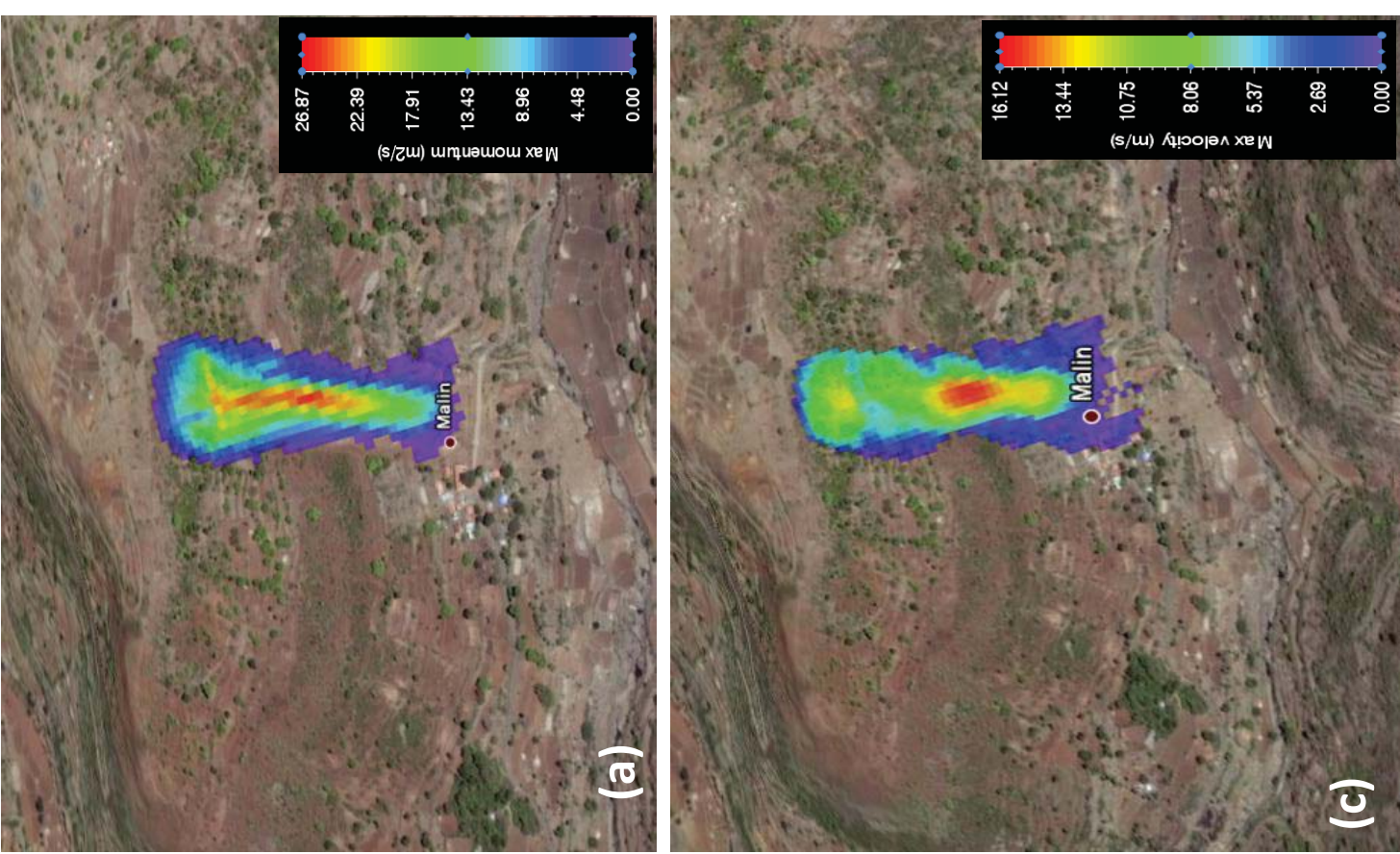
Nat. Hazards Earth Syst. Sci. Discuss., https://doi.org/10.5194/nhess-2017-382

Manuscript under review for journal Nat. Hazards Earth Syst. Sci.

Discussion started: 11 January 2018

(c) Author(s) 2018. CC BY 4.0 License.
Natural Hazards and Earth System

Sciences

\begin{tabular}{|c|c|c|c|c|c|c|c|c|}
\hline 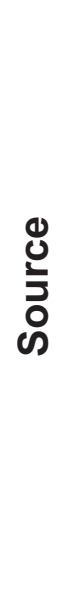 & 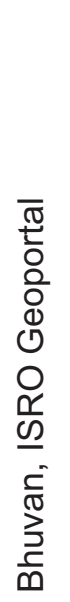 & \multicolumn{2}{|c|}{ 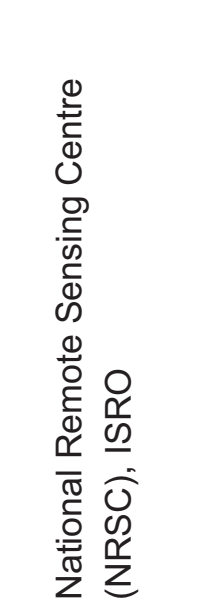 } & 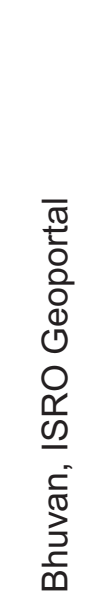 & 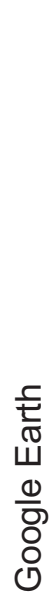 & 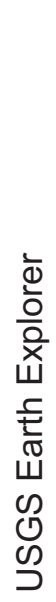 & 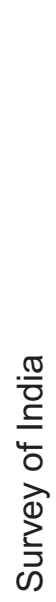 & 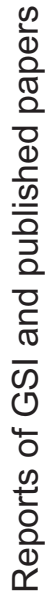 \\
\hline 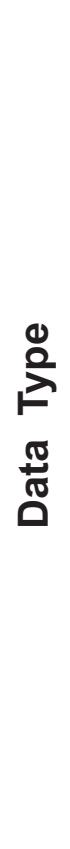 & 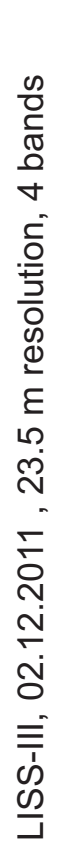 & 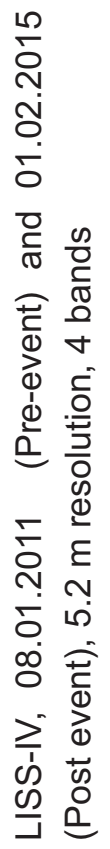 & 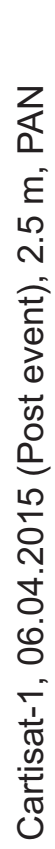 & 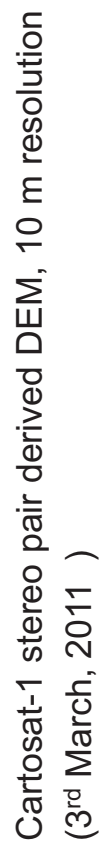 & 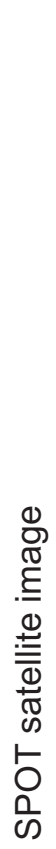 & 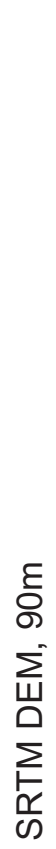 & 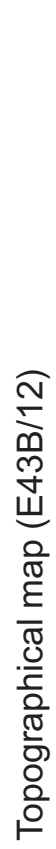 & 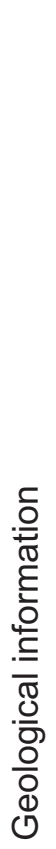 \\
\hline
\end{tabular}

